\title{
Fecundity and survival of Anagyrus kamali (Hymenoptera: Encyrtidae) under different feeding and storage temperature conditions
}

\author{
Laurent A. SAGARRA ${ }^{1,2}$, Charles VINCENT ${ }^{3}$, and Robin K. STEWART ${ }^{1}$ \\ ${ }^{1}$ Department of Natural Resource Sciences, Macdonald Campus of McGill University, Sainte-Anne-de-Bellevue, QC, H9X 3V9, \\ Canada \\ ${ }^{2}$ P.R. Trinidad Ltd., Orange Grove Estate, Tacarigua, Trinidad \& Tobago \\ ${ }^{3}$ Horticultural Research and Development Center, Agriculture and Agri-Food Canada, 430 Gouin Blvd., Saint-Jean-sur-Richelieu, \\ QC, J3B 3E6, Canada; e-mail: vincentch@em.agr.ca
}

\begin{abstract}
Key words. Anagyrus kamali, Encyrtidae, parasitoid, Maconellicoccus hirsutus, hibiscus mealybug, Pseudococcidae, storage, fecundity, survival, egg load
\end{abstract}

\begin{abstract}
The parasitoid, Anagyrus kamali Moursi (Hymenoptera: Encyrtidae), has been recently introduced into the Caribbean as a biological control agent against the hibiscus mealybug (HMB), Maconellicoccus hirsutus Green (Homoptera: Pseudococcidae). Storage of $A$. kamali that is essential for its use in biological control did not affect the longevity of female and male parasitoids (40.3 \pm 14.07 and $31.7 \pm 9.57$ days, respectively) when kept at $20 \pm 2{ }^{\circ} \mathrm{C}$ in absence of hosts and fed ad libitum with droplets of pure honey. At a storage temperature of $27 \pm 2^{\circ} \mathrm{C}$ the longevity decreased by about 10 days. Fed females did not resorb eggs during the first two weeks of storage at $20 \pm 2^{\circ}$. Parasitoid ovogenesis ceased when ovarioles/lateral oviducts were full. The lifetime fecundity was not significantly affected by a storage at $20 \pm 2^{\circ} \mathrm{C}$ of up to 14 days. Foraging activities and oviposition were the main factors influencing the lifespan of female $A$. kamali.
\end{abstract}

\section{INTRODUCTION}

Maconellicoccus hirsutus Green (Homoptera: Pseudococcidae), commonly named the hibiscus or pink mealybug (HMB), was accidentally introduced into the island of Grenada in 1994 and has been inexorably spreading throughout the Caribbean islands where it has become a major pest on several crops. It is now present in 18 Caribbean islands, and also in Guyana (I.I.E., 1997). M. hirsutus is a very prolific pest with females laying between 384-540 eggs (Mani, 1989). It injects a toxin at the point of feeding, causing severe distortion of leaves, new shoots and fruit (Williams, 1996), and attacks a wide range of fruit trees, ornamentals, forest trees and weeds (i.e. 125 host species - Mani, 1989).

Anagyrus kamali Moursi (Hymenoptera: Encyrtidae), a solitary endoparasitoid, was imported from China by the CABI International Institute of Biological Control (IIBC), $\mathrm{UK}$, for classical biological control of this pest in the Caribbean. As part of the Technical Co-operation Program funded by the Food and Agriculture Organisation (FAO) of the United Nations for the biological control of $M$. hirsutus, A. kamali is currently shipped from Trinidad to several countries in the Caribbean and South America. Parasitoids in transit may be stored for periods of 4 to 10 days between emergence in the rearing facilities and field release. This might result in mortality, and possibly a decrease of lifetime fecundity due to resorption of mature eggs, negatively affecting the efficiency of the released parasitoids.

Little has been published on the biology and behavior of this parasitoid except for Moursi (1948) and Sagarra and Vincent (1999) and Sagarra et al. (2000). Our objectives were to determine (1) the effect of storage conditions on the survival of the parasitoid; and (2) the impact of storage on the egg load of adult female parasitoids, lifetime fecundity and oviposition period.

\section{MATERIALS AND METHODS}

\section{Rearing of $M$. hirsutus}

Mealybugs were reared on sprouted potatoes in nylon mesh cages ( 32 sprouted potatoes per cage) supported on steel wire frames $(48 \times 48 \times 68 \mathrm{~cm})$. The cultures were maintained in the dark at $27 \pm 2^{\circ} \mathrm{C}$. Each week 64 sprouted potatoes were individually infested with 20 adult female mealybugs having wellformed ovisacs. Weekly infestations ensured a continuous supply of different $M$. hirsutus nymphal instars. Three weeks after infestation, the potatoes had $M$. hirsutus populations that mainly consisted of L2 (second instar) and L3 (third instar) mealybugs. Cohorts of adult females with ovisacs were available after 4-6 weeks. Size was used as the primary criterion to distinguish M. hirsutus stages (Ghose, 1971).

In each experiment we used L3 female, and the early adult female (preovisac). L3 and adults $M$. hirsutus were sexed using characteristics described in Ghose (1971).

\section{Rearing of the parasitoid}

Each week, $100 \mathrm{~A}$. kamali adult females were released into two cages each containing 32 infested potatoes supporting threeweek old populations of $M$. hirsutus. Insects were maintained at $27 \pm 2^{\circ} \mathrm{C}, 60 \pm 10 \% \mathrm{RH}$, under a photoperiod of $12 \mathrm{~L}: 12 \mathrm{D}$. Light was provided by two fluorescent lamps $(70 \mathrm{~W})$ suspended $30 \mathrm{~cm}$ above the cages. Two weeks after the release of the parasitoids, mummies were collected from the potatoes and individually placed in gelatin capsules. Mummies were observed daily and newly ( $<24 \mathrm{~h}$ ) emerged parasitoids were used for 
experiments. All parasitoids used for experiments were the same size (1.5-1.8 $\mathrm{mm}$ in length).

\section{Longevity}

Newly $(<24 \mathrm{~h})$ emerged female and male parasitoids were individually placed in transparent plastic vials $(7 \mathrm{~cm}$ long, $2 \mathrm{~cm}$ in diameter) with a $1 \mathrm{~cm}$ hole covered with fine mesh cloth in the cap. The effect of temperature and food supply was assessed by storing half of the insects (i.e. 60 males and 60 females) at 27 $\pm 2{ }^{\circ} \mathrm{C}$ and the other half (i.e. 60 males and 60 females) at $20 \pm$ $2^{\circ} \mathrm{C}$. Within each temperature treatment, half of the parasitoids (i.e. 30 males and 30 females) were fed with droplets of pure honey and the other half (i.e. 30 males and 30 females) were not fed. Observations were made at $24 \mathrm{~h}$ intervals to determine the longevity of the adults. For each of the eight combinations sextemperature-food treatment, 30 parasitoids were tested. t-tests ( $\mathrm{p} \leq 0.05$ ) were used to compare longevities. Interaction between temperature and food supply was determined using two-way ANOVA (Systat 7.0 for Windows). Cohort survival curves (fraction of each cohort surviving at a particular moment in time) were plotted and compared using the Weibull frequency distribution model. The proportion of individuals surviving at time $\mathrm{t}$ is given by:

$$
\mathrm{F}(\mathrm{t})=1-\exp \left(-\left[(\mathrm{t} / \mathrm{b})^{\mathrm{c}}\right]\right)
$$

Where $\mathrm{b}$ and $\mathrm{c}$ are the scale and shape parameters of the distribution (Pinder et al., 1978). These parameters were estimated and compared using Systat 7.0 for Windows.

\section{Egg load}

Groups of ten newly $(<24 \mathrm{~h})$ emerged female and five male parasitoids were stored in transparent plastic vials (as described above). The parasitoids were stored at $20 \pm 2^{\circ} \mathrm{C}$ and fed daily with droplets of pure honey. Every second day, ten of the stored female parasitoids were dissected and the number of mature oocytes (Moursi, 1948) was recorded. Insects were not dissected beyond 14 days, as this represented the maximum storage period. Egg loads were compared using a t-test (Systat 7.0 for Windows).

\section{Fecundity after storage}

Groups of ten newly ( $<24 \mathrm{~h}$ ) emerged female parasitoids were stored in transparent plastic vials (as described above). Ten male parasitoids were also introduced into each vial in order to ensure mating. The parasitoids were kept at $20 \pm 2{ }^{\circ} \mathrm{C}$ and fed daily with droplets of pure honey. Batches of parasitoid females were stored for $1,4,7,10$, and 14 days. Fecundity was assessed for each of these periods.

Third-instar mealybugs were collected from potato sprouts and placed in groups of 20 on a hibiscus (Hibiscus rosa-sinensis L.) leaf. The hibiscus leaf was then placed inside a cylindrical transparent plastic vial $(10 \mathrm{~cm}$ in diameter, $6 \mathrm{~cm}$ in height $)$ with a $1 \mathrm{~cm}$ hole covered with mesh on the screw cap. One female parasitoid was introduced into each vial and fed with a drop of honey deposited on the mesh window of the cap. The parasitoids were left to forage and oviposit for $24 \mathrm{~h}$. The adult parasitoids were then removed and transferred to another vial with 20 new mealybugs for another $24 \mathrm{~h}$. This was repeated until the death of the parasitoids. Parasitized mealybugs were dissected in a drop of ethanol (70\%) and the number of parasitoid eggs in each host was recorded. Oviposition tests were conducted at 27 $\pm 2{ }^{\circ} \mathrm{C}, 60 \pm 10 \% \mathrm{RH}$. Fifteen parasitoids were tested for each storage period (total of 75 parasitoids tested). The data were analyzed with ANOVA and means were separated with Tukey tests ( $\mathrm{p} \leq 0.05)$ (Systat 7.0 for Windows).

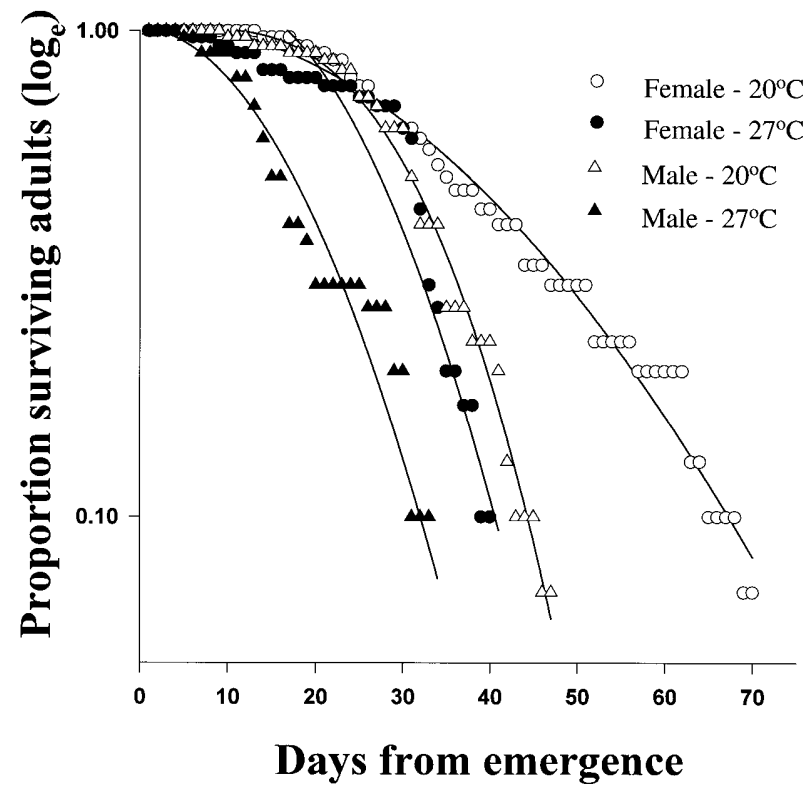

Fig. 1. Adult survival (days) of female and male $A$. kamali at $20 \pm 2$ and $27 \pm 2^{\circ} \mathrm{C}(\mathrm{n}=30$ individuals per temperature-sex combination).

\section{RESULTS}

\section{Longevity}

Female parasitoids lived longer than males in all treatments ( $\mathrm{p} \leq 0.05$ ). Anagyrus kamali individuals that were fed on honey lived longer than individuals stored without food at both temperature treatments $(\mathrm{p} \leq 0.05)$ (Table 1, Fig. 1). Unfed parasitoids did not survive beyond $48 \mathrm{~h}$ at both $20 \pm 2$ and $27 \pm 2{ }^{\circ} \mathrm{C}$. However, A. kamali fed on honey survived significantly longer $(\mathrm{p} \leq 0.05)$ when stored at $20 \pm 2$ than at $27 \pm 2{ }^{\circ} \mathrm{C}$. Female longevity dropped from $40.3 \pm 14.07$ to $29.0 \pm 9.94$ days, and male longevity from $31.7 \pm 9.57$ to $18.9 \pm 8.92$ days (Table 1 , Fig. 1). At $20 \pm 2{ }^{\circ} \mathrm{C}$ with food supply a maximum longevity of 71 days was recorded for female parasitoids and 48 days for male parasitoids. Median lethal time $50\left(\mathrm{LT}_{50}\right)$ occurred at 36 and 22 days at respectively $20 \pm 2$ and 27 $\pm 2^{\circ} \mathrm{C}$ for the female parasitoids, and after 21 days at $20 \pm$ $2^{\circ} \mathrm{C}$ and 18 days at $27 \pm 2^{\circ} \mathrm{C}$ for male parasitoids, respectively (Table 2). If stored at $20 \pm 2^{\circ} \mathrm{C}$ with regular food supply, female parasitoids could survive up to 28 days, and males up to 23 days before reaching $10 \%$ mortality.

Cohort survival curves (Fig. 1) were plotted only for parasitoids which were provided with food, as unfed indi-

TABLE 1. Average $(\mathrm{n}=30$ individuals) longevity (days) male and female adult $A$. kamali, according to food type and temperature, in absence of hosts (i.e. no oviposition).

\begin{tabular}{lccr}
\hline \multirow{2}{*}{ Food supply } & \multirow{2}{*}{$\begin{array}{c}\text { Temperature } \\
\left({ }^{\circ} \mathrm{C}\right) \pm 2\end{array}$} & \multicolumn{2}{c}{ Mean $( \pm \mathrm{SD})$ longevity (days) } \\
\cline { 3 - 4 } & & \multicolumn{1}{c}{ Female } & Male \\
\hline Control (no food) & 20 & $1.7 \pm 0.47 \mathrm{~b}^{*}$ & $1.3 \pm 0.47 \mathrm{a}$ \\
Control (no food) & 27 & $1.8 \pm 0.41 \mathrm{~b}$ & $1.1 \pm 0.31 \mathrm{a}$ \\
Pure honey & 20 & $40.3 \pm 14.07 \mathrm{e}$ & $31.7 \pm 9.57 \mathrm{~d}$ \\
Pure honey & 27 & $29.0 \pm 9.94 \mathrm{~d}$ & $18.9 \pm 8.92 \mathrm{c}$ \\
\hline
\end{tabular}

* Pairs of means within rows and columns followed by the same letters are not significantly different (t-test, $\mathrm{P}<0.05$ ). 
TABLE 2. Survival analysis data of $A$. kamali fed with honey, according to the sex and temperature $(\mathrm{n}=$ 30 individuals - means $\pm \mathrm{SD}$ ).

\begin{tabular}{lccccc}
\hline & \multicolumn{2}{c}{ Male } & & \multicolumn{2}{c}{ Female } \\
\cline { 2 - 3 } \cline { 5 - 6 } & $20 \pm 2{ }^{\circ} \mathrm{C}$ & $27 \pm 2{ }^{\circ} \mathrm{C}$ & & $20 \pm 2{ }^{\circ} \mathrm{C}$ & $27 \pm 2{ }^{\circ} \mathrm{C}$ \\
\hline Weibull parameter $\mathrm{b}$ & $23.9 \pm 2.30 \mathrm{a}^{*}$ & $20.3 \pm 2.13 \mathrm{a}$ & & $40.2 \pm 3.00 \mathrm{~b}$ & $27.7 \pm 2.57 \mathrm{a}$ \\
Weibull parameter $\mathrm{c}$ & $1.73 \pm 0.225 \mathrm{a}$ & $1.69 \pm 0.245 \mathrm{a}$ & & $1.66 \pm 0.168 \mathrm{a}$ & $1.64 \pm 0.205 \mathrm{a}$ \\
$\mathrm{LT}_{50}$ & 21.5 & 18.0 & & 36.0 & 24.6 \\
\hline
\end{tabular}

* Within rows, pairs of means followed by the same letters are not significantly different (t-test, $\mathrm{p}<0.05$ ).

viduals did not survive long enough to perform this analysis. At both temperatures, the shape of the cohort survival curves of the fed parasitoids was of type I (Weibull $\mathrm{c}>1$ - Table 2) (Pinder et al., 1978), the age specific mortality rate increasing with age. A t-test performed on the value of the $b$ parameter (scale parameter of the distribution) showed that survival of females at 20 $\pm 2{ }^{\circ} \mathrm{C}$ was significantly (t-test, $\mathrm{p} \leq 0.05$ ) greater than females and males stored at $27 \pm 2^{\circ} \mathrm{C}$.

\section{Egg load}

The number of mature oocytes in A. kamali females increased during the first four days, rising from $29.1 \pm$ 6.25 mature oocytes to $41.2 \pm 7.18$. There was no significant difference between egg load of female parasitoids stored between 4 to 14 days $(p>0.05)$, with an average of $43.0 \pm 12.2$ mature eggs (Fig. 2).

\section{Fecundity}

A. kamali oviposited successfully after all the storage periods tested. Lifetime fecundity (total number of eggs oviposited through the parasitoid lifespan) was not significantly $(p>0.05)$ affected by the increase of the storage period, the total number of eggs oviposited going from $99.9 \pm 24.9$ after one day of storage to $74.2 \pm 32.5$ after two weeks (Table 3). The oviposition period was also not significantly different $(\mathrm{p}>0.05)$ according to the storage period, which went from $9.4 \pm 3.17$ days after one day storage to $7.3 \pm 2.87$ days after two weeks. The oviposition rate increased during the first three days of ovi-

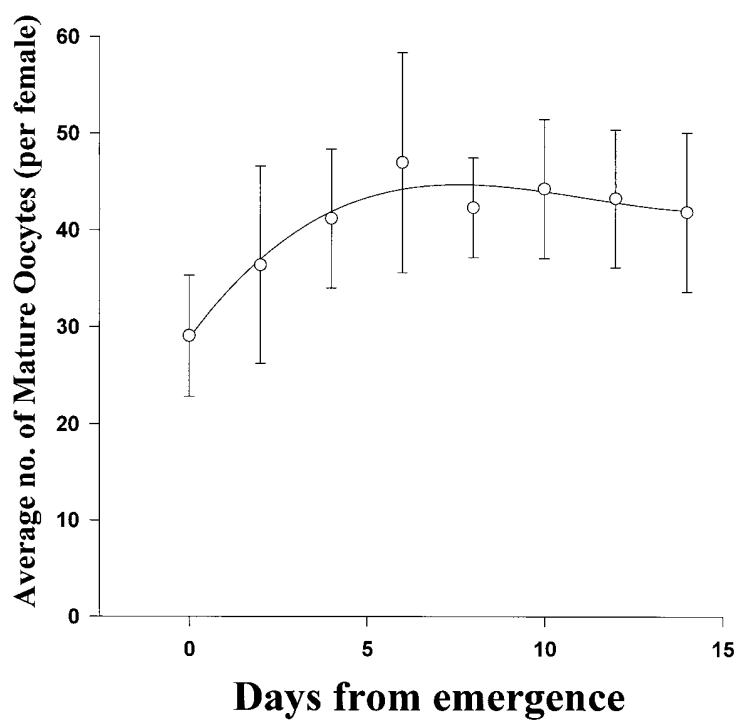

Fig. 2. Average number of mature oocytes of female $A$. kamali from 0 to 14 days after emergence at $20 \pm 2^{\circ} \mathrm{C}(\mathrm{n}=10$ females per treatment). position, and then gradually decreased until it reached a plateau at the end of oviposition period (Fig. 3). The slope and the value of the plateau of the curves corresponding to 10 and 14 days of storage were less than (average of $20 \%$ ) for 7 days of storage curves, showing a decrease in oviposition rate. The longevity of the parasitoid significantly increased with an increase of the storage

TABLE 3. Average lifetime fecundity and oviposition period of A. kamali according to the storage period prior to first oviposition ( $\mathrm{n}=15$ individuals, $27 \pm 2^{\circ} \mathrm{C}$ ).

\begin{tabular}{|c|c|c|c|}
\hline \multirow{2}{*}{$\begin{array}{l}\text { Storage } \\
\text { period } \\
\text { (days) }\end{array}$} & \multicolumn{3}{|c|}{ Mean $( \pm \mathrm{SD})$} \\
\hline & $\begin{array}{l}\text { Lifetime fecundity } \\
\text { (eggs \#) }\end{array}$ & $\begin{array}{l}\text { Oviposition } \\
\text { period (days) }\end{array}$ & $\begin{array}{l}\text { Total longevity } \\
\text { (days) }\end{array}$ \\
\hline 1 & $99.9 \pm 24.94 \mathrm{a}^{*}$ & $9.4 \pm 3.17 \mathrm{a}$ & $9.4 \pm 3.17 \mathrm{a}$ \\
\hline 4 & $100.1 \pm 21.29 \mathrm{a}$ & $9.0 \pm 3.27 \mathrm{a}$ & $13.0 \pm 3.27 b$ \\
\hline 7 & $99.4 \pm 23.37 \mathrm{a}$ & $9.8 \pm 2.90 \mathrm{a}$ & $16.8 \pm 2.90 \mathrm{bc}$ \\
\hline 10 & $84.3 \pm 29.72 \mathrm{a}$ & $8.5 \pm 3.90 \mathrm{a}$ & $18.5 \pm 3.90 \mathrm{~cd}$ \\
\hline 14 & $74.2 \pm 32.48 \mathrm{a}$ & $7.3 \pm 2.87 \mathrm{a}$ & $21.3 \pm 2.87 \mathrm{~d}$ \\
\hline
\end{tabular}

* Within columns, pairs of means followed by the same letter are not significantly different (Tukey, $\mathrm{P}<0.05$ ).

period, the parasitoid lifespan going from $9.4 \pm 3.2$ to $21.3 \pm 2.9$ days after one and 14 days, respectively.

\section{DISCUSSION}

\section{Longevity test}

Large insects tend to live longer than small insects (Godfray, 1994). This positive correlation between body

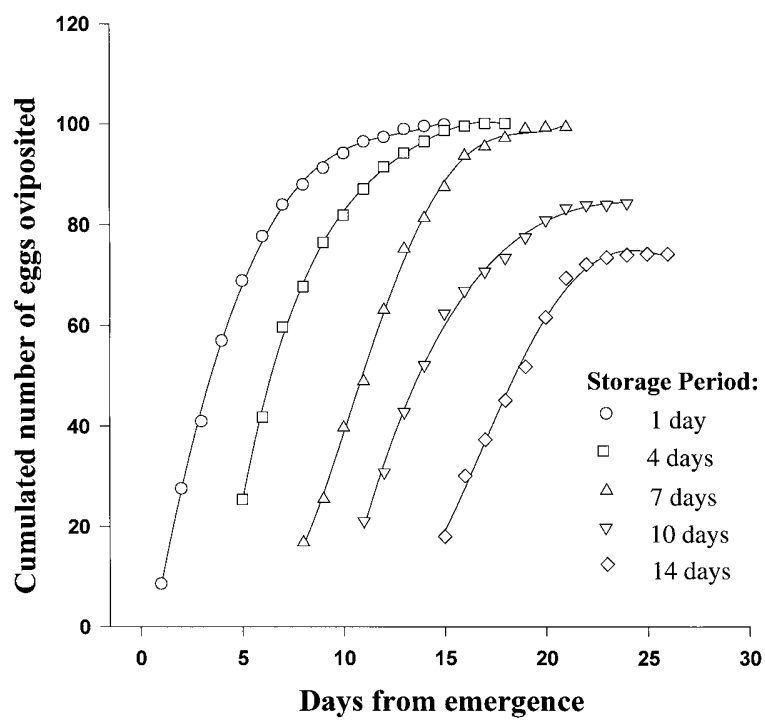

Fig. 3. Cumulative fecundity of female A. kamali following storage period from 1 to 14 days ( $\mathrm{n}=15$ individuals per storage period). 
size of adults and their longevity has been shown for several parasitoid species (Harvey et al., 1994; Waage \& Ng, 1984). In $A$. kamali, females are generally larger and they have a greater longevity than males.

Food is also an important factor for parasitoid survival, and it is essential to ensure mating and subsequent foraging and oviposition of the parasitoid (van Lenteren et al., 1987; Finch \& Coaker, 1969). Adult A. kamali that were provided with food lived approximately 20 times longer than unfed individuals. Moursi (1948) recorded a maximum longevity of 131 days for $A$. kamali during the Egyptian winter at temperatures under $20^{\circ} \mathrm{C}$. In our study, out of the 240 tested parasitoids a maximum of 71 days was recorded for two individual female parasitoids at 20 $\pm 2{ }^{\circ} \mathrm{C}$. Host feeding did not affect positively the adult parasitoid longevity since in the fecundity tests, where $A$. kamali females were exposed to their host and could host feed on them, their average longevity was $9.4 \pm 3.2$ days.

The impact of temperature on longevity of $A$. kamali was significant. Storage at $20 \pm 2^{\circ} \mathrm{C}$ increased the average survival period by approximately $30 \%$ for both female and male fed parasitoids, as a result of a reduction in their activity.

For other Anagyrini species, like Anagyrus mangicola Noyes, the average survival of male and female parasitoids at $25 \pm 2^{\circ} \mathrm{C}$ was shorter than $A$. kamali, with $16.7 \pm$ 0.46 and $20.2 \pm 0.30$ days, respectively (Cross \& Moore, 1992). Similar trends were observed for longevity of Anagyrus pseudococci (Girault) and Leptomastix abnormis (Girault) (Tingle \& Copland, 1989), and also Anagyrus dactylopii (Howard) (Mani \& Thontadarya, 1988).

\section{Egg load}

The egg load of the parasitoid determines the number of eggs the female can lay at any given time. As a synovogenic species, only a fraction of $A$. kamali oocytes are mature at emergence, and four days are required to fill the ovarioles with mature oocytes (41.2 \pm 7.18 oocytes). Similar observations were also made for the synovogenic species Coccophagus atratus Compère (Hymenoptera: Aphelinidae) (Donaldson \& Walter, 1988).

\section{Lifetime fecundity}

The impact of storage period on the lifetime fecundity of parasitoids has been reported for only one other Encyrtid species, Anabrolepis mayurai Subba Rao, a parasitoid of the sugarcane scale, Melanaspis glomerata (Green) (Dutta \& Devaiah, 1988). In this species, the storage period negatively affected the lifetime fecundity of the parasitoid. In A. kamali, neither lifetime fecundity nor oviposition period were significantly affected during the storage periods tested in this study. The females generally oviposited more eggs during the first three to four days of their oviposition period. Oviposition and foraging activities had a profound effect on $A$. kamali longevity since the oviposition period was the same for parasitoids stored for 1-14 days. These activities appeared to exhaust the resources of the parasitoid and shorten its survival time. Hohmann et al. (1989) observed the same phenomenon with Trichogramma platneri Nagarkatti, where oviposition was the main factor influencing the lifespan of female parasitoids.

\section{Implications for mass-production and biological control shipments}

Emerging parasitoids should be supplied with food to increase their longevity. Storage periods of four to ten days between emergence and release of the parasitoids should cause minimal losses as $97 \%$ of the female parasitoids and $93 \%$ of the male parasitoids stored at $20 \pm 2{ }^{\circ} \mathrm{C}$ with a food supply were alive after 14 days. The fecundity of A. kamali can be sustained for up to 14 days if they are stored at $20 \pm 2{ }^{\circ} \mathrm{C}$. Thus, the parasitoid can be collected, stored for a period of several days and that should allow for shipments of high quality parasitoids.

ACKNOWLEDGEMENTS. We thank N. Peters for technical assistance. We thank J. Etienne, INRA/URPV Petit Bourg Guadeloupe, French West-Indies, and D.E. Meyerdirk, USDA/APHIS, Maryland, USA, for commenting an early version of the manuscript. This is contribution no. 335/2000.03.02R of Horticultural Research and Development Research Center, Agriculture and Agri-Food Canada, SaintJean-sur-Richelieu, QC, Canada.

\section{REFERENCES}

Cross A.E. \& Moore D. 1992: Developmental studies on Anagyrus mangicola (Hymenoptera: Encyrtidae), a parasitoid of the mealybug Rastrococcus invadens (Homoptera: Pseudococcidae). Bull. Entomol. Res. 82: 307-312.

Dutta S.K. \& Devaiah M.C. 1988: Effect of age on fecundity of Anabropelis mayurai Subba Rao, a parasitoid of the sugar cane scale, Melanaspis glomerata (Green). J. Res. Assam Agric. Univ. 9: 1-2, 50-53.

DONALDSON J.S. \& WALTER G.H. 1988: Effect of egg availability and egg maturity on the oviposition activity of the parasitic wasp, Coccophagus atratus. Physiol. Entomol. 13: 407-417.

FINCH S. \& COAKER T.H. 1969: Comparison of the nutritive values of carbohydrates and related compounds to Erioischia brassicae. Entomol. Exp. Appl. 12: 441-453.

GHOSE S.K. 1971: Morphology of various instar of both sexes of the mealybug Maconellicoccus hirsutus (Green) (Pseudococcidae: Hemiptera). Indian J. Agric. Sci. 41: 602-611.

Godfray H.C.J. 1994: Parasitoids, Behavioral and Evolutionary Ecology. Princeton University Press, Princeton, 473 pp.

Harvey J.A., Harvey I.F. \& Thompson D.J. 1994: Flexible larval feeding allows use of a range of host size by parasitoid wasp. Ecology 75: 1420-1428.

Hommann C.L., Luck R.F., Oatman E.R. \& Platner G.R. 1989: Effects of different biological factors on longevity and fecundity of Trichogramma platneri Nagarkatti (Hymenoptera: Trichogrammatidae). Anais Soc. Entomol. Brasil 18: 61-70.

I.I.E. 1997: Distribution map of pest, Series A (Agricultural) map \#100 (2nd revision) Maconellicoccus hirsutus. International Institute of Entomology, London.

Mani M. 1989: A review of the pink mealybug - Maconellicoccus hirsutus (Green). Insect Sci. Appl. 10: 157-167.

Mani M. \& Thontadarya T.S. 1988: Biology of the grape mealybug parasitoid, Anagyrus dactylopii (How) (Encyrtidae: Hymenoptera). Entomon 13: 3-4, 211-213.

Moursi A.A. 1948: Anagyrus kamali Moursi, a parasite of the Hibiscus Mealybug, Phenacoccus hirsutus Green. Bull. Soc. Fouad I. Entomol. 32: 9-16. 
Pinder J.E., Wiener J.G. \& Smith M.H. 1978: The Weibull distribution: a new method of summarizing survivorship data. Ecology 59: 175-179.

SAGARRA L.A. \& VinCENT C. 1999: Influence of host stage on oviposition, development, sex ratio, and survival of Anagyrus kamali Moursi (Hymenoptera: Encyrtidae), a parasitoid of the hibiscus mealybug, Maconellicoccus hirsutus Green (Homoptera: Pseudococcidae). Biol. Control 15: 51-56.

Sagarra L.A., Peterkin D.D., Vincent C. \& Stewart R.K 2000: Immune response of the hibiscus mealybug, Maconellicoccus hirsutus Green (Homoptera: Pseudococcidae) to oviposition of the parasitoid Anagyrus kamali Moursi (Hymenoptera: Encyrtidae). J. Insect Physiol. 46: 647-653.

SYSTAT 7.0 FOR WINDOWs. 1997: SPSS Inc, Chicago IL.

Tingle C.C.D. \& Copland M.J.W. 1989: Progeny production and adult longevity of the mealybug parasitoids Anagyrus pseudococci, Leptomastix dactylopii, and Leptomastidea abnormis (Hym.: Encyrtidae)- in relation to temperature.
Entomophaga 34: 111-120.

Van Lenteren J.C., van Vianen A., Gast H.F. \& Kortenhoff A. 1987: The parasite-host relationship between Encarsia formosa Gahan (Hymenoptera: Aphelinidae) and Trialeurodes vaporariorum Westwood (Homoptera: Aleyrodidae), XVI. Food effects on oogenesis, lifespan and fecundity on Encarsia formosa and other hymenopterous parasites. Z. Angew. Entomol. 103: 69-84.

WAAGE J.K. \& NG S.M. 1984: The reproductive strategy of a parasitic wasp. I. Optimal progeny and sex allocation in Trichogramma evanescens. J. Anim. Ecol. 53: 401-416.

WiLliaMs D.J. 1996: A brief account of the hibiscus mealybug Maconellicoccus hirsutus (Hemiptera: Pseudococcidae), a pest of agriculture and horticulture, with descriptions of two related species from southern Asia. Bull. Entomol. Res. 86: 617-628.

Received June 28, 1999; accepted February 3, 2000 